imaging findings, and clinical symptoms. Chest. 2003;124: 2068-73.

3. Burke A, Virmani R. Tumors of the heart and the great vessels. En: Atlas of tumor pathology. Fascicle 16, 3 rd series. Washington, DC: Armed Forces Institute of Pathology; 1996.

4. Zukotynski KA, Israel DA, Kim CK. FDG uptake in lipomatous hypertrophy of the interatrial septum is not likely related to brown adipose tissue. Clin Nucl Med. 2011;36:767-9.

5. Prior JT. Lipomatous hypertrophy of cardiac interatrial septum: A lesion resembling hibernoma, lipoblastomatosis and infiltrating lipoma. Arch Pathol. 1964;78:11-5.

6. Nadra I, Dawson D, Schmitz SA, et al. Lipomatous hypertrophy of the interatrial septum: A commonly misdiagnosed mass often leading to unnecessary cardiac surgery. Heart. 2004;90:e66.

7. Arbarello P, Maiese A, Bolino G. Case study of sudden cardiac death caused by lypomatous hypertrophy of the interatrial septum. Med Leg J. 2012;80:102-4.

8. Koshida Y, Watanabe G, Tomita S, et al. Right atrial lipomatous hypertrophy resection and reconstruction using autologus pericardium. Surg Today. 2012;42:1104-6.
9. Sheikh M, Hasan S, Kanjwal Y, et al. Syncope as an initial manifestation of atypical lipomatous hypertrophy of the interatrial septum. J Card Surg. 2012;27:454-7.

10. Di Bella G, Mileto A, Gaeta M, et al. Atrial lipomatous hypertrophy causing reduction in systemic venous return. Herz. 2011;36:147-8.

Juan Parejo-Matos*, Francisco López-Pardo

y Justo Manuel Rodríguez-Rodríguez

Servicio de Cardiología, Hospital Universitario Virgen del Rocío, Sevilla, España

* Autor para correspondencia: C/Castillo de Alcalá de Guadaira 15, 5. ${ }^{\circ}$ C; 41013 Sevilla; España.

Teléfono: +41666738563.

Correo electrónico: jparejo84@gmail.com

(J. Parejo-Matos).

http://dx.doi.org/10.1016/j.acmx.2013.07.009

\section{Implantación transfemoral de la válvula aórtica Edwards SAPIEN XT en una aorta extremadamente tortuosa}

\section{Implantation transfemoral aortic valve Edwards SAPIEN XT in a patient with extreme tortuous aorta}

La estenosis aórtica es la enfermedad valvular más frecuente en adultos, y la sustitución valvular quirúrgica con prótesis valvulares biológicas o mecánicas ha sido durante muchos años el patrón de referencia para el tratamiento de las estenosis valvulares importantes ${ }^{1}$. El riesgo de una cirugía es más elevado en la población anciana que frecuentemente tiene comorbilidades asociadas y la implantación percutánea de la válvula aórtica es una opción de tratamiento en estos pacientes ${ }^{2}$. En la actualidad, los datos disponibles están basados en 2 prótesis, la Edwards SAPIEN XT (Edwards Lifesciences, EE. UU.) y la Medtronic CoreValve (Medtronic, Inc., EE. UU. $)^{3}$. Ambas prótesis inicialmente requerían un introductor de 22 a $24 \mathrm{Fr}$, pero en la actualidad la válvula SAPIEN XT es montada y sube por un sistema de liberación llamado NovaFlex (Edwards Lifesciences, EE. UU.), con un diámetro de 16-18 $\mathrm{Fr}^{4}$.

Con los avances en la tecnología, en nuestros tiempos se pueden tratar válvulas aórticas en pacientes con aortas muy tortuosas que antes eran consideradas una contraindicación para el implante de válvula aórtica percutánea. Se describe el caso de una mujer de 86 años con estenosis aórtica sintomática, diabetes, hipertensión arterial, dislipidemia y fibrilación auricular crónica. Se realizó un ecocardiograma transesofágico que demostró una estenosis aórtica, con un área valvular de $0.56 \mathrm{~cm}^{2}\left(0.40 \mathrm{~cm}^{2} / \mathrm{m}^{2}\right)$ y un gradiente medio de $82 \mathrm{mmHg}$. El diámetro del anillo fue de $19 \mathrm{~mm}$, con insuficiencia aórtica leve; y una fracción de expulsión del ventrículo izquierdo del 55\%. En la coronariografía se observaron arterias coronarias sin lesiones significativas y en el aortograma una aorta extremadamente tortuosa y una aorta ascendente en posición horizontal con respecto al plano valvular ${ }^{5,6}$ (fig. 1A). En la sesión médico-quirúrgica se concluyó que la paciente tenía un EuroSCORE logístico del $12 \%$ y alto riesgo quirúrgico por presentar una deformidad torácica importante. Por estas razones se decidió realizar implante percutáneo de válvula aórtica ${ }^{6}$. Se utilizó como acceso terapéutico (acceso arterial donde se sube la prótesis) la arteria femoral común izquierda con un introductor expandible $18 \mathrm{Fr}$ (E-Sheath). La marcada tortuosidad de la aorta torácica hizo el acceso difícil solo para cruzar la válvula aórtica y especialmente el intercambio de la guía recta 0.35" por la guía Amplatz extra-stiff (Cook Medical Inc, Bloomington, Ind., EE. UU.). Se decidió utilizar un catéter terapéutico multipropósito de $7 \mathrm{Fr}$, y con las 2 guías en paralelo en la punta del catéter se introdujo la guía recta dentro del ventrículo izquierdo para pasar inmediatamente la guía extra-stiff (fig. 1B y C) preformada dentro del ventrículo izquierdo y no se observó ninguna dificultad en el resto del procedimiento. La valvuloplastia se realizó de manera habitual con el balón de $20 \mathrm{~mm}$ (fig. 1D), y se avanzó la válvula Edwards SAPIEN XT (Edwards Lifesciences, EE. UU.) n. ${ }^{\circ} 23$ sin dificultad y con apoyo del catéter liberador NovaFlex (fig. 1E). Se posicionó la válvula y fue implantada con la estimulación ventricular rápida. En el aortograma posprocedimiento no se observó insuficiencia aórtica, y el ecocardiograma periprocedimiento mostró una excelente aposición de la prótesis sin insuficiencia (fig. 1F). La paciente fue dada de alta a los 7 días sin complicaciones. En el ecocardiograma antes del alta se confirmó una adecuada posición de la válvula con un gradiente medio de $10 \mathrm{mmHg}$, sin insuficiencia aórtica. En el seguimiento clínico al año, la paciente se encontró en clase funcional । de la NYHA.

La calcificación extensa en el lugar del acceso femoral, así como la tortuosidad extrema han sido identificadas como factores adicionales de aparición de complicaciones vasculares mayores ${ }^{7}$. La extrema tortuosidad de la aorta 

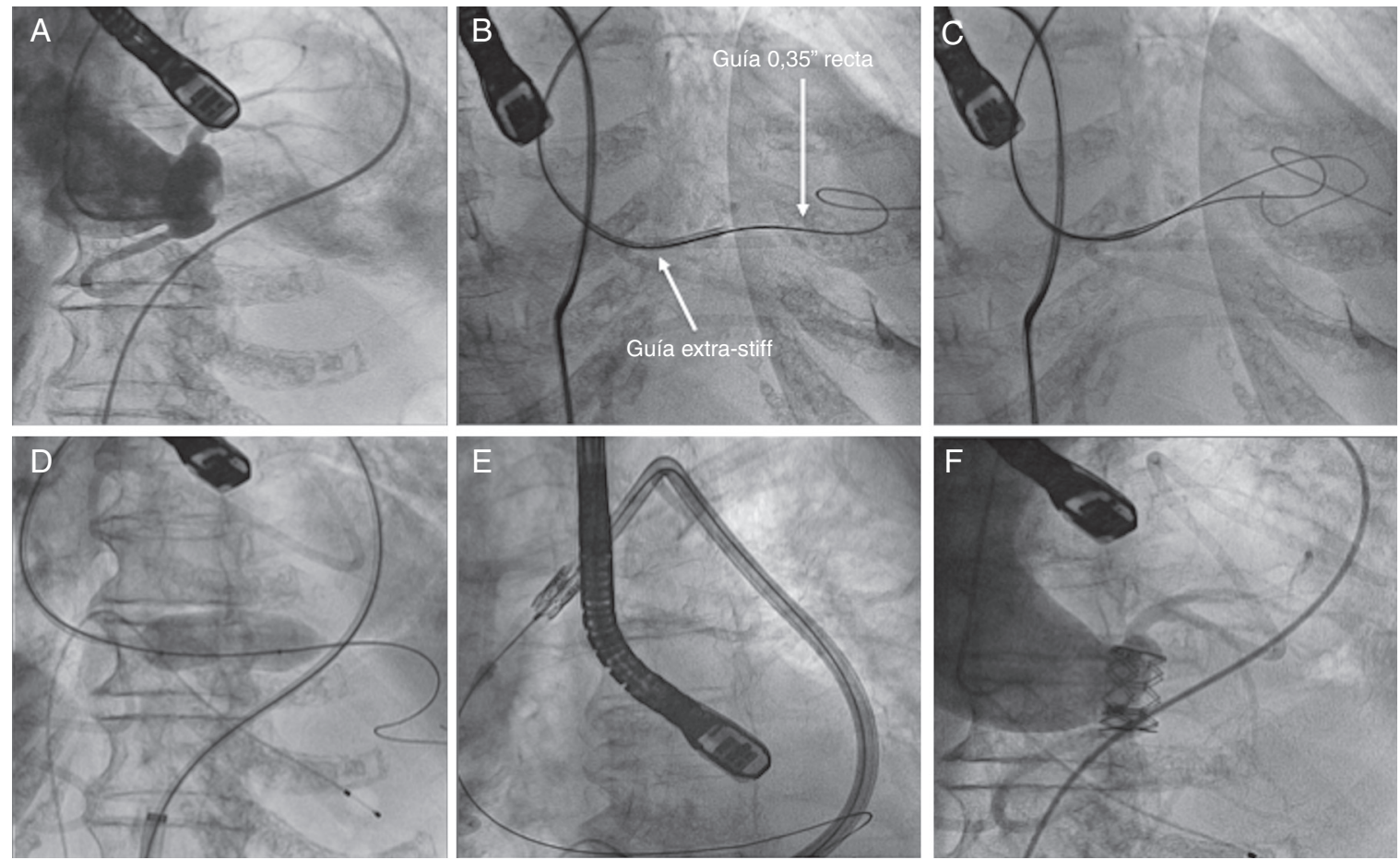

Figura 1 Aortograma preprocedimiento (A); paso de una guía de $0.35^{\prime \prime}$ recta y una guía extra-stiff casi en paralelo a través de la válvula aórtica $(B$ y C); valvuloplastia con balón (D); la válvula avanza y es posicionada (E); aortograma posterior a la implantación sin insuficiencia $(F)$.

puede ser una contraindicación para el implante percutáneo de válvula aórtica, sin embargo en este caso nosotros consideramos que el procedimiento era factible dadas las características de la válvula Edwards SAPIEN XT y el sistema de liberación de la válvula, ya que la flexibilidad y variabilidad en la flexión del catéter NovaFlex facilita la implantación transfemoral de la Edwards SAPIEN XT. En este caso clínico estaba indicado el tratamiento percutáneo de la estenosis aórtica, y muy especialmente vía transfemoral. Ya hemos tenido algunos casos con tortuosidad extrema en el implante percutáneo de la válvula aórtica exitoso, y pensamos desde un principio que podíamos llevar a cabo el procedimiento. Otra dificultad que tenía la paciente era una raíz aórtica horizontal (un ángulo de $90^{\circ}$ entre el plano valvular), sin embargo lo hace factible igualmente el manejo del catéter liberador de la válvula Edwards SAPIEN XT.

Nuestro centro tiene experiencia con algunos pacientes con aorta muy tortuosa e implante percutáneo de la válvula aórtica de forma exitosa. Esta experiencia nos hizo pensar que en este caso donde la aorta era extremadamente tortuosa, la trataríamos con éxito. Este tratamiento percutáneo es una buena alternativa para los pacientes con estenosis aórtica importante, con la aorta extremadamente tortuosa, y el procedimiento puede llevarse a cabo de forma segura, con posibilidades de éxito con la válvula Edwards SAPIEN XT y el sistema de liberación NovaFlex (que hace al dispositivo manejable, pudiendo manipular la dirección en las diferentes angulaciones). En este caso no se presentó ninguna dificultad al subir la válvula en todo el trayecto de la aorta y la única dificultad fue el cruce de las guía por la válvula aórtica nativa.Financiación
No se recibió patrocinio de ningún tipo para llevar a cabo este artículo.

\section{Conflicto de Intereses}

Los autores declaran no tener ningún conflicto de intereses.

\section{Bibliografía}

1. Eltchaninoff $\mathrm{H}$, Zajarias A, Tron $\mathrm{C}$, et al. Transcatheter aortic valve implantation: Technical aspects, results and indications. Arch Cardiovasc Dis. 2008;101:126-32.

2. Masson JB, Kovac J, Schuler G, et al. Transcatheter aortic valve implantation: Review of the nature, management, and avoidance of procedural complications. JACC Cardiovasc Interv. 2009;2:811-20.

3. Vahanian A, Himbert D, Brochet E. Transcatheter valve implan tation for patients with aortic stenosis. Heart. 2010;96:1849-56.

4. Holmes Jr DR, Mack MJ, Kaul S, et al., American College of Cardiology Foundation; American Association for Thoracic Surgery; Society for Cardiovascular Angiography and Interventions; Society for Thoracic Surgeons; American Heart Association; American Society of Echocardiography; European Association for CardioThoracic Surgery; Heart Failure Society of America; Mended Hearts; Society of Cardiovascular Anesthesiologists; Society of Cardiovascular Computed Tomography; Society for Cardiovascular Magnetic Resonance. 2012 ACCF/AATS/SCAI/STS expert consensus document on transcatheter aortic valve replacement: Developed in collaboration with the American Heart Association, American Society of Echocardiography, European Association for Cardio-Thoracic Surgery, Heart Failure Society of America, Mended Hearts, Society of Cardiovascular Anesthesiologists, Society of Cardiovascular Computed Tomography, and 
Society for Cardiovascular Magnetic Resonance. Ann Thorac Surg. 2012;93:1340-95.

5. Webb JG, Altwegg L, Boone RH, et al. Transcatheter aortic valve implantation. Impact on clinical and valve related outcomes. Circulation. 2009;119:3009-16.

6. Rodés-Cabau J, Dumont E, DeLaRochellière R, et al. Feasibility and initial results of percutaneous aortic valve implantation including selection of the transfemoral or transapical approach in patients with severe aortic stenosis. Am J Cardiol. 2008;102:1240-4.

7. Hayashida K, Lefèvre T, Chevalier B, et al. Transfemoral aortic valve implantation. New criteria to predict vascular complications. J Am Coll Cardiol Intv. 2011;4:851-8.
Patricia Martín-Hernández*, Rosana Hernández-Antolín y Eulogio García-Fernández

Servicio de Cardiología Intervencionista, Hospital Clínico San Carlos, Madrid, España

* Autora para correspondencia. Departamento de Hemodinámica, 2. ${ }^{\circ}$ piso, puerta G, C/Profesor Martín Lagos, S/N, Madrid, C.P. 28040, España.

Correo electrónico: paty_martin75@hotmail.com

(P. Martín-Hernández).

http://dx.doi.org/10.1016/j.acmx.2013.08.005

\section{Heart calcification (idiopathic cardiac osseous metaplasia): A case report}

\section{Calcificación cardiaca (Metaplasia osea cardiaca idiopática: reporte de un caso)}

\section{To the Editor,}

Myocardial calcification is an unusual entity. The first report appeared in 1919 when Scholz $z^{1}$ observed a calcified heart in an X-ray film. A heart may develop calcifications in different locations such as valves, arteries, endocardium, pericardium and conduction tissue. ${ }^{2,3}$ Degenerative and inflammatory mechanisms have been postulated as possible explanations for these calcifications. Intra-myocardial calcification is extremely rare and has been associated with pathological entities such as chronic renal failure, particularly if treated with hemodialysis, and secondary hyperparathyroidism. ${ }^{4}$

It has also been associated to previous myocardial damage such as that due to myocarditis, ${ }^{5,6}$ cardiac trauma, scarring after cardiac surgery ${ }^{7}$ or calcium deposits in the area of a post-infarction aneurysm. ${ }^{8}$ There are reports based on nonscientific observations that refer to other potential causes such as tuberculomas, radiation or the toxic effect of vasoactive amines. ${ }^{9-11}$ In this article we report the case of a female patient who did not present any of the previously referred conditions, but developed singularly distributed severe calcification within the left ventricular myocardial tissue, which led to significant restriction of diastolic filling. She underwent cardiac transplantation and the explanted heart revealed interesting findings.

At the time of this report, the patient was 56 years old, with a female born, and a resident of Mexico City, from a middle income socio-economic level. She had no relevant family, traumatic or infectious disease history.

She was admitted to our hospital in 2007 with a 2-year history of dyspnea on strenuous exertion that progressed to dyspnea on mild exertion. Physical examination only revealed the presence of an $\mathrm{S} 4$.

The chest X-ray film showed widespread radio-opaque areas within the left ventricle, surrounding it in a spiral pattern.
The CT scan of the four chambers at the papillary muscle level showed calcium infiltrations of the myocardium (Fig. 1A). Myocardial calcium infiltration was evident (B), when observed from the inferior wall of the left ventricle (B).

This same study excluded mediastinal great vessel or pulmonary parenchymal involvement. More calcifications in other organ systems were intentionally sought but not found.

Cardiac catheterization showed extensive calcification distributed in bands and with the respective areas (calcium free) protruding between the calcium bands during ventricular diastole. (Fig. 1C and D) Coronary arteries were normal and the hemodynamic curves showed a restrictive filling pattern.

An 18FDG-PET scan did not show any metabolic abnormalities suggesting increased glycolytic activity throughout the body.

Systemic, autoimmune, infectious, rheumatic and metabolic processes relating to the detected calcifications were duly excluded.

A myocardial biopsy obtained from the left ventricle revealed cellular hypertrophy, areas with amphiphilic material with a patchy distribution between muscle fibers and negative staining, thus except for the deposition of mucoid substances, calcium or amyloid. $H$ and $E$ staining showed no inflammatory infiltrates. PAS, Gram and Grocott staining were also negative. Neoplastic cells were not observed.

The patient continued to deteriorate clinically, developed dysnea and fainting spells with minimal exertion that required cardiac transplantation with a favorable outcome. The explanted heart was studied in detail as shown in Fig. 2: macroscopic Fig. 2A and B of the explanted heart in a coronal section showed multiple intra-myocardial calcifications. Microphotographs $2 C$ and D $(10 \times$ and $40 \times$, respectively) stained with hematoxylin and eosin. C: a bony spicule (arrow) replaces residual cardiac muscle. D: a laminated spicule (arrow) is seen on the left and residual cardiac muscle on the right. Consequently, tissue areas were replaced by spongy bone trabeculae with bone marrow in their interior; no interstitial fibrosis or microorganisms were observed.

Two well-known mechanisms explain myocardial calcification: metastatic calcification and dystrophic calcification. 